\title{
Zwi(ch)nięte koło radykalnohermeneutyczne
}

ABSTRACT. Szaj Patryk, Zwi(ch)nięte koło radykalnohermeneutyczne [Twisted radical-hermeneutic circle]. „Przestrzenie Teorii” 30. Poznań 2018, Adam Mickiewicz University Press, pp. 231-245. ISSN 1644-6763. DOI 10.14746/pt.2018.30.11.

The article is an interpretation of the traditional figure of the hermeneutic circle made from the perspective of John D. Caputo's radical hermeneutics. It begins with a recapitulation of the most important modern positions on the hermeneutic circle, which postmodern hermeneutics radicalizes, noting the impossibility of its closure or fulfillment. Movement in the postmodern hermeneutic circle takes place not between the parts and the whole, but only between the different parts. Thus, one might say that this circle is twisted, and this has a dual meaning. It evokes Jacques Derrida's interpretation of a phrase from Hamlet, "time is out of joint", but it also plays with the meaning of the twist, which can be understood as a Verwindung: the impossibility of the transgression beyond modern hermeneutics.

KEYWORDS: radical hermeneutics, deconstruction, hermeneutic circle

\section{Nowoczesne koło hermeneutyczne - metoda czy "struktura rozumienia"?}

Najpopularniejsza formuła koła hermeneutycznego, głosząca, że rozumienie dzieła sztuki ma postać kolista, poruszając się od części do całości i od całości do części, jest wynalazkiem Friedricha Schleiermachera ${ }^{1}$. Na gruncie myśli autora Hermeneutik und Kritik ma ona charakter postulatu metodologicznego, wprzęgniętego $\mathrm{w}$ - równie kolista - metodę interpretacji, poruszającej się pomiędzy wymiarem psychologicznym (subiektywnym) i gramatycznym (obiektywnym) dzieła oraz pomiędzy dywinacją (specyficznym wczuciem w intencje autora tekstu) i działaniem porównawczym. Metodologiczne ograniczenia podzielają także rozmaite literaturoznawcze ujęcia koła hermeneutycznego, proponowane na przykład przez Emila Staigera, twierdzącego, że pierwsze podejście do tekstu literackiego jest swoistym doświadczeniem „ducha, który ożywia całość”, dookreślanym w kolejnych lekturach ${ }^{2}$, czy przez Paula Ricoeura, próbującego godzić ze sobą teorie hermeneutyczne i strukturalistyczne na podstawie twierdzenia, iż rozumienie jest jedynie „naiwnym uchwyceniem znaczenia tekstu jako całości”, które

${ }^{1}$ Zob. F. Schleiermacher, Hermeneutics and Criticism. And Other Writings, przeł. A. Bowie, Cambridge 1998 (szczególnie część General Hermeneutics, s. 225-268).

${ }^{2}$ Zob. E. Staiger, Die Kunst der Interpretation. Studien zur deutschen Literaturgeschichte, München 1963, s. 13. 
musi zostać zweryfikowane przez analityczne wyjaśnianie, gwarantujące obiektywne „pojęcie” sensu3. Kolisty ruch interpretacji przebiega więc tu od rozumienia, przez wyjaśnianie, do pojęcia.

W kole hermeneutycznym widziano jednak często - czynili tak nieraz sami hermeneuci, na przykład Peter Szondi ${ }^{4}$ - błędne koło. Jak bowiem miałoby ono jednocześnie być metodą interpretacji tekstu oraz stanowić sam warunek rozumienia, a przy tym gwarantować jego „całościowość”? „Całościowość”, która - dodajmy - jest raczej postulatem niż rzeczywistym punktem dojścia procesu interpretacji, z czego zresztą zdawał sobie sprawę już Wilhelm Dilthey ${ }^{5}$. Uwagi te wskazują na ograniczenia metodologicznych ujęć koła hermeneutycznego, jednocześnie jednak pozwalają zauważyć, że jawi się ono jako błędne tylko wtedy, gdy pojmiemy je - w wąski i, koniec końców, nieuprawniony sposób - właśnie jako postulat metodologiczny. Podejście metodologiczne ujmuje bowiem koło przestrzennie, podczas gdy właściwiej byłoby je pojąc temporalnie $e^{6}$ : w rzeczywistości ruch kolisty to nie tyle jakieś metodyczne działanie, ile sama, jak najwydatniej pokazał Hans-Georg Gadamer, ,struktura rozumienia”. Koło hermeneutyczne nie trzyma się kurczowo raz obranego kierunku, przeciwnie - jest procesualne, umożliwia skorygowanie wyjściowej postawy, a nawet go wymaga, warunkując „ciagłe projektowanie-na-nowo”" własnych antycypacji sensu „w obliczu rzeczy”, której dotyczy rozumienie. Nawet więc jeśli przystępujemy do rozumienia z pewnym „źródłowym” oczekiwaniem (a czynimy tak z pewnościa, obarczeni własnymi przedsądami, autorytetem tradycji, dziejowościa, a także - co do listy Gadamera dodałyby nowsze nurty humanistyki - płciowościa, uwarunkowaniem kulturowym i politycznym, a nawet ideologia), to nasza antycypacja sensu całości wciąż jest dookreślana (i, chciałoby się dodać, od-określana) przez części, skłaniające do jej nieustannej re-aranżacji. Ruch po kole hermeneutycznym polega więc na oddzielaniu ziaren

${ }^{3}$ P. Ricoeur, Język, tekst, interpretacja, przeł. P. Graff, K. Rosner, wstęp K. Rosner, Warszawa 1989, s. 160.

${ }^{4}$ Zob. P. Szondi, Wprowadzenie do hermeneutyki literackiej, [w:] Wspótczesna myśl literaturoznawcza $w$ Republice Federalnej Niemiec. Antologia, wybór, oprac. i wstęp H. Orlowski, Warszawa 1986, s. 26.

${ }^{5}$ „może ona [interpretacja] zrealizować swoje zadanie tylko w określonym stopniu: wszelkie rozumienie pozostaje zawsze tylko względne i nigdy nie może się zakończyć" (W. Dilthey, Powstanie hermeneutyki, [w:] tegoż, Pisma estetyczne, przeł. K. Krzemieniowa, Warszawa 1982, s. 309-310. Cyt. za: Z. Dziuban, Obcośc, bezdomność, utrata. Wymiary atopii wspótczesnego doświadczenia kulturowego, Poznań 2009, s. 20).

${ }^{6}$ Zob. na ten temat W.V. Spanos, Heidegger, Kierkegaard, and the Hermeneutic Circle: towards a postmodern theory of interpretation as dis-closure, [w:] Martin Heidegger and the Question of Literature, ed. W.V. Spanos, Bloomington and London 1979.

${ }^{7}$ H.-G. Gadamer, Prawda i metoda. Zarys hermeneutyki filozoficznej, przeł. B. Baran, Warszawa 2004, s. 369. 
od plew, przedsądów właściwych od niewłaściwych, antycypacji trafnych od nietrafnych. „Kto chce rozumieć - mówi Gadamer - ten nie zda się na przypadkowość własnego poglądu wstępnego [...]. Kto chce rozumieć tekst, ten, przeciwnie, jest gotowy pozwolić mu coś sobie powiedzieć"8.

Autor Prawdy i metody daje do zrozumienia, że metodologiczne ujęcia koła hermeneutycznego nie odzwierciedlaja w pełni jego radykalizmu wydobytego przez Martina Heideggera. To właśnie autor Bycia i czasu pokazał, że rozumienie nie jest - jak chcieli jeszcze Schleiermacher czy Dilthey ${ }^{9}$ - jakąś specyficzną metodą nauk humanistycznych, ale - o wiele bardziej „,́́ródłowo” - fundamentalnym modusem bycia Dasein, tego „bytu, któremu jako byciu-w-świecie o nie samo chodzi”" ${ }^{10}$. Jako takie, ma ono kolistą strukturę co najmniej z dwóch powodów: po pierwsze, dane jest zawsze na gruncie określonych przedrozumień, umożliwiających - jak mówi Heidegger - wstępny zasób, wstępny ogląd i wstępne pojęcie, które z kolei strukturyzują sens jako „to, w czym utrzymuje się zrozumiałość czegoś”11 (a więc nie coś immanentnie przynależnego bytom, ale swoistą przestrzeń rozumienia); po drugie, jest (zawsze już) samorozumieniem, wyznaczając relację zwrotna pomiędzy Dasein a światem: „w każdym rozumieniu świata współrozumiana jest egzystencja i na odwrót"12. Jeśli więc w ogóle można mówić o rozumieniu jako metodzie postępowania, to byłaby ona wtórna względem tej podstawowej rozumiejącej postawy człowieka wobec świata, nadpisując się nad nią, ale też wydatnie przykrawając jej sensotwórcze działanie $(\mathrm{RH}, 79-80)^{13}$.

Radykalizm egzystencjalnego koła hermeneutycznego polega na przewartościowaniu tradycyjnej relacji logicznej pomiędzy potencjalnością i aktualnościa. Analityka egzystencjalna Dasein zmierza do ukazania jego fun-

${ }^{8}$ Tenże, Koło jako struktura rozumienia, przeł. G. Sowiński, [w:] Wokót rozumienia. Studia i szkice z hermeneutyki, red. G. Sowiński, Kraków 1993, s. 230.

${ }^{9}$ Przy czym rola Diltheya byłaby tu niejednoznaczna. Autorzy nowszych opracowań skłonni są właśnie w nim, a nie w Heideggerze, upatrywać twórcę współczesnej filozofii hermeneutycznej (zob. na przykład A. Przyłębski, Hermeneutyczna antropologia Wilhelma Diltheya, [w:] tegoż, Krytyka hermeneutycznego rozumu. Preliminaria, Kraków 2016).

${ }^{10}$ M. Heidegger, Bycie i czas, przeł. B. Baran, Warszawa 2010, s. 195.

${ }^{11}$ Tamże, s. 206.

12 Tamże, s. 207.

${ }^{13}$ Cytaty z pism Johna D. Caputo - ze względu na ich dużą częstotliwość - lokalizuję bezpośrednio w tekście, przyjmując następujące skróty: RH - Radical Hermeneutics. Repetition, Deconstruction and the Hermeneutic Project, Bloomington-Indianapolis 1987; AE - Against Ethics. Contributions to a Poetics of Obligation with Constant Reference to Deconstruction, Blooming 1993; DH - Demythologizing Heidegger, Bloomington and Indianapolis 1993; PT Prayers and Tears of Jacques Derrida. Religion without Religion, Bloomington and Indianapolis 1997; MRH - More Radical Hermeneutics: On Not Knowing Who We Are, Bloomington and Indianapolis 2000; HTRK - How to Read Kierkegaard, New York 2007. 
damentalnego otwarcia, które Heidegger nazywa także „rzuceniem” w „tu oto”, w faktyczność istnienia. Otwartość sprawia, że rozumienie ma zawsze strukturę projektu, rozwijanego ze względu na możliwości egzystencjalne Dasein: „Projektowy charakter rozumienia konstytuuje bycie-w-świecie co do otwartości jego «tu oto» jako «tu oto» pewnej możności bycia"14. Oznacza to, że Dasein nie tyle jest (na sposób obecności), ile projektuje się - nie może być rozpatrywane od strony statycznego bytu, lecz od strony dynamicznego bycia, gdyż samo stanowi pewna „możność bycia”, ,jest pierwotnie byciem-możliwym”, „jest zawsze tym, czym może być”"15. Dlatego właśnie John D. Caputo, autor koncepcji hermeneutyki radykalnej, mówi, że „powtórzenie [jakie dokonuje się w kole hermeneutycznym - przyp. PS] zwraca się nie ku aktualności, lecz ku możliwości. Możliwość jest wyżej niż aktualność" (RH, 91). Produktywność rozumienia konstytuuje bowiem, jak stara się pokazać Caputo (ale także inni komentatorzy Heideggera ${ }^{16}$ ), inną niż substancjalna koncepcję tożsamości. Byłaby ona nie tyle podstawa podmiotu, ile zadaniem do osiagnięcia (RH, 29), które jednak ruch po kole hermeneutycznym stale odracza:

Możliwość w sensie modalnej kategorii obecności oznacza coś jeszcze nie rzeczywistego i nigdy nie koniecznego. Charakteryzuje ona coś tylko możliwego. Ontologicznie stoi niżej niż rzeczywistość i konieczność. Możliwość jako egzystencja natomiast to najbardziej pierwotny i ostateczny pozytywny ontologiczny określnik jestestwa ${ }^{17}$.

Ruch po kole hermeneutycznym stanowi więc egzystencjalny odpowiednik arystotelesowskiego kinesis, który - cytując Caputo - „istnieje» we wzajemnej wymianie potencjalności i aktualności, nie będąc ani jedną, ani druga, gdyż jest tą przestrzenią pomiędzy [in-between land], która sama opisuje dynamikę wolności” (RH, 16). Koło hermeneutyczne nie jest błędnym kołem, gdyż określa egzystencjalną prestrukturę Dasein. Nie da się go po prostu pozbyć, ale też nie da się postawić go jako metodologicznego postulatu. Jak podkreśla Heidegger, „nie chodzi tu o podporządkowanie rozumienia i wykładni określonemu ideałowi poznania", lecz o to, że Dasein zawsze już mieści się w kole, „ma ontologiczna strukturę koła” ${ }^{18}$, i właśnie dlatego może - paradoksalnie - stawać się tym, kim już jest (RH, 30), i odwrotnie: wciąż nawracać do „tego samego”, co de facto nie jest już „tym samym”, gdyż każde powtórzenie to jednocześnie przemieszczenie, iteracja wyjściowego problemu (RH, 68). Jak trafnie zauważa Zuzanna Dziuban, cyrkularność

\footnotetext{
${ }^{14}$ M. Heidegger, Bycie i czas..., s. 198.

${ }^{15}$ Tamże, s. 196.

${ }^{16}$ Zob. na przykład K. Rosner, Narracja, tożsamość i czas, Kraków 2003.

${ }^{17}$ M. Heidegger, dz. cyt., s. 196.

18 Tamże, s. 208, 209.
} 
rozumienia jest nie tyle postulatem, ile fenomenem ${ }^{19}$. Wszystko to umożliwia autorowi Bycia $i$ czasu postawienie słynnej tezy, że „decydujące jest nie tyle wydobycie się z owego koła, ile odpowiednie w nie wejście"20. Koło hermeneutyczne stanowi bowiem nie metafizyczne uroszczenie, idealistyczną mrzonkę, pięknoduchowski postulat, ale - jak komentuje tę kwestię Gadamer - „radykalizację postępowania, które w istocie zawsze podczas rozumienia realizujemy. [...] W ten sposób przedsięwzięcie hermeneutyczne zyskuje twardy grunt pod nogami”21. Właściwe wejście w koło oznacza nieufność wobec własnych przedsądów, nieustanną weryfikację wstępnych mniemań, wrażliwość na inność (np. inność tekstu). Warunkuje tym samym (tym-innym-samym) ciagłe utrzymywanie koła w ruchu (RH, 11-12).

\section{Radykalne koło hermeneutyczne}

Po tych wyjściowych rozpoznaniach i rekonstrukcjach pora jednak postawić pytanie: czy problem koła hermeneutycznego jako radykalizacji procesu rozumienia został przez hermeneutykę nowoczesną postawiony wystarczająco radykalnie? Jakie zastrzeżenia, korekty, uzupełniania mogłaby tu wprowadzić hermeneutyka ponowoczesna, rozwijana przede wszystkim w dialogu z myślą Jacques'a Derridy? Co „przejście przez ogień dekonstrukcji” (RH, 119), które według Caputo odbiera hermeneutyce naiwność i niewinność, czyniłoby z kołem hermeneutycznym? Czy wystawienie koła na działanie différance, będącej, zdaniem autora Radical Hermeneutics, jedynie radykalizacją hermeneutycznej skończoności (MRH, 43), nie załamywałoby jego ruchu pomiędzy częścią i całością? Czy nie wskazywałoby, że „gra”, jaką koło umożliwia, jest już z góry zabezpieczona, tak że „piłka nigdy nie wykracza poza granice boiska" (RH, 113)? Czy, w konsekwencji, umożliwiane przez koło otwarcie horyzontu rozumienia nie byłoby także pewnym zamknięciem?

Aby odpowiedzieć na te pytania, warto raz jeszcze powrócić do Heideggerowskiej analityki egzystencjalnej, z której wyprowadzić można wniosek, iż Dasein jest zawsze już czymś więcej niż (f)aktualnie jest. Ta dwuznaczna formuła wskazywałaby - po pierwsze - że „nigdy nie jest ono «obecne» czy całkowicie zaktualizowane" (RH, 69), więc skończone, dopełnione, ostateczne, ale też - po drugie - że wykracza ono poza swój faktualny byt, wciąż otwarte na nowe możliwości bycia. To jednak znaczyłoby, że ruch po kole hermeneu-

\footnotetext{
${ }^{19}$ Zob. Z. Dziuban, dz. cyt., s. 20.

${ }^{20}$ Tamże, s. 208.

${ }^{21}$ H.-G. Gadamer, Prawda i metoda..., s. 370-371.
} 
tycznym traci perspektywę całościowa, ulega przesunięciu w kierunku gry śladów (i śladów śladów) nigdy nieuzyskujących dopełnienia. Heidegger:

w jestestwie zawsze jeszcze coś zalega, co jako możność bycia jego samego nie stało się jeszcze „rzeczywiste”. Istota podstawowego ukonstytuowania jestestwa zawiera zatem ciagła niezamkniętość. Taki brak całokształtu oznacza zaległość możności bycia. [...] Dopóki jestestwo jest jako byt, nigdy nie osiaga swej „zupełności” (Gänze) ${ }^{22}$.

Jeśli więc zadaniem rozumienia jest cyrkularny nawrót do tego samego (Heidegger mówi: „każdy myśliciel myśli tylko jedną jedyną myśl”"23), co de facto nie jest już tym samym, ale się przemieszcza, dopełnia, rozwija, otwiera na własne inne, to „całość”, „obecność”, samo „dopełnienie” byłyby jedynie hipostazami, efektami gry dokonującego się w kole hermeneutycznym powtórzenia: „re-prezentacja poprzedza i umożliwia tę obecność, która jakoby od-twarza”, zaś „powtórzenie jest «starsze» niż to, co powtarza” (RH, 4). Koło hermeneutyczne wystawia Dasein na upływ (znaczeń, sensów, życia), uniemożliwiając ustatecznienie, stabilizację, powstrzymanie gry powtarzalności, która skierowana jest nie w tył, ku czemuś minionemu, ale w przód. Jak bowiem za Sørenem Kierkegaardem twierdzi Caputo, właściwe powtórzenie - w przeciwieństwie do przypomnienia, anamnesis - nie nawraca wcale ku czemuś byłemu, lecz jest ruchem egzystencjalnym rzutowanym w przyszłośćc ${ }^{24}$. Nie ma więc nic z późnoheideggerowskiego Andenken, pragnącego powrócić do źródeł i restytuować to, co minione (DH, 17-18), bliżej mu zaś do wspomnianej już Derridiańskiej iteracji: nieustannego przesuwania, przeinaczania, samoporóżnienia, które wrzuca podmiot w kondycję radykalnohermeneutyczna.

Dlatego hermeneutyka ta - jak pisze Norbert Leśniewski - nie prowadzi do komfortowej konkluzji, lecz do burzliwych trudności życia. [...] Z tego to głównie powodu koło hermeneutyczne nie jest błędnym kołem - nie jest nigdy poznawczo pełniejsze, lecz bardziej problematyczne: nie kończy się ostatecznym pojęciem istoty, lecz dociera do punktu wyjścia - do problemu bycia ${ }^{25}$.

Radykalne koło hermeneutyczne jest więc wyraźnie wykoślawione albo jak mówi Edward Kasperski - skołowane ${ }^{26}$. Nie ma w nim już - bo być nie

${ }^{22}$ M. Heidegger, dz. cyt., s. 312.

${ }^{23}$ Tenże, Co zwie się myśleniem?, przeł. J. Mizera, Warszawa-Wrocław 2000, s. 30.

${ }^{24}$ S. Kierkegaard, Powtórzenie. Próba psychologii eksperymentalnej przez Constantina Constantiusa, [w:] tegoż, Powtórzenie. Przedmowy, przeł. i oprac. B. Świderski, Warszawa 2000 , s. $15-17$.

${ }^{25}$ N. Leśniewski, O hermeneutyce radykalnej, Poznań 1998, s. 161.

${ }^{26}$ Zob. E. Kasperski, Hermeneutyka. Teoria interpretacji, [w:] Literatura, teoria, metodologia, red. D. Ulicka, wyd. 2, Warszawa 2001, s. 134-136. Por. też G. Deleuze, Różnica i powtórzenie, przeł. B. Banasiak, K. Matuszewski, Warszawa 1997, gdzie koło wiecznego powrotu zostało określone jako „wygięte”, „ekscentryczne” i „zdecentrowane” (s. 145). 
może - ruchu od części do całości i od całości do części, jest raczej (formuła Tadeusza Różewicza okazuje się tu nader trafna) „zawsze fragment”. Kiedy więc hermeneutyka nowoczesna formułowała problem koła, zatrzymywała się wpół kroku. Widać to szczególnie w myśli Gadamera, u którego perspektywa całościowa jest jeszcze bardzo wyraźna. Twierdzi on nawet, że „zestrojenie wszystkich szczegółów w całość jest w każdym przypadku probierzem trafności rozumienia. Brak takiego zestroju równia się niepowodzeniu próby zrozumienia" ${ }^{27}$. Do lektury tekstu przystępuje się bowiem zawsze z pewnym z góry zaprojektowanym sensem całości, który wprawdzie „stale podlega rewizji w świetle rezultatów dalszego wnikania w sens" ${ }^{28}$, ale - w konsekwencji - w całkiem harmonijny i zgoła heglowski sposób ulec musi ostatecznemu dopełnieniu. Rodzi się tu jednak pytanie: czy hermeneutyka Gadamerowska nie wikła się tym samym w wewnętrzna sprzeczność? Albo, by postawić je w nieco słabszy sposób czy postulat osiagnięcia pełni zrozumienia jest na jej gruncie realizowalny? Wszak sam autor Prawdy i metody mówi, że „rozumieć to zawsze rozumieć inaczej”, że rozumienie nie ma żadnego określonego telosu, że „zły to hermeneuta, który sobie wyobraża, że może lub musi mieć ostatnie słowo" ${ }^{29}$. Nie przeszkadza mu to jednak zakładać „presupozycji pełni”, głoszącej, „iż tylko to jest zrozumiałe, co rzeczywiście prezentuje sobą pełną jedność sensu. Czytając tekst, zawsze zakładamy jego pełnię"30. Zdaniem Caputo dzieje się tak, gdyż Gadamer jest po prostu

bardziej „egalitarnym” heglista, heglistą rozsądnie twierdzącym, że absolut nigdy nie przyjmuje absolutnej i kanonicznej formy, że sama struktura historyczności uniemożliwia absolutną instancję absolutu. Nie jest to [jednak - przyp. PS] heglizm bez absolutu, ale heglizm, w którym absolutowi brak absolutnej wykładni. (RH, 111)

Tym, czego Gadamer przede wszystkim nie dopuszcza, jest właśnie Derridiańska logika śladu, który - cytując dalej autora Radical Hermeneutics - „nie na-śladuje i nie kopiuje oryginału, ale wytwarza, produkuje efekty, na-znacza, poprzedza i czyni możliwymi wszelakie jedności - "znaczenia», «bycia», a nawet «języka» - w obrębie których operuje Gadamerowska hermeneutyka" (RH, 53).

${ }^{27}$ H.-G. Gadamer, Koto jako struktura rozumienia..., s. 227.

${ }^{28}$ Tamże, s. 229.

${ }^{29}$ Tenże, Prawda i metoda..., s. 757.

${ }^{30}$ Tenże, Koło jako struktura rozumienia..., s. 231. Warto jednak zauważyć, że u Gadamera obecna jest także tendencja przeciwstawna: „Nie znaczy to, że nieokreślone oczekiwanie sensu, które sprawia, iż dzieło staje się dla nas ważne, może za każdym razem znaleźć całkowite spełnienie, tak byśmy ze zrozumieniem i z aprobata mogli sobie przyswoić pełny sens. [...] Oczekiwanie, że można w pojęciu zebrać sensowne treści, jakimi sztuka do nas przemawia, zawsze niebezpiecznie pozostawiało sztukę gdzieś w tyle” (H.-G. Gadamer, Aktualność piękna. Sztuka jako gra, symbol i święto, przeł. K. Krzemieniowa, Warszawa 1993, s. 44-45). 
Krytyki Caputo (i, rzecz jasna, Derridy) nie ustrzega się jednak także Heidegger. Czy otwarcie, jakie oferuje horyzont rozumienia, to rzeczywiście pełne otwarcie? Czy nie jest tak, że widzimy/rozumiemy w nim tylko to, co on sam sobą obejmuje, a mianowicie: jedynie możliwości bycia? Przecież poza „możliwościami”, jak powiada Miron Białoszewski, ,jeszcze się czają niemożliwości”"31 - to wszystko, co poza, ponad czy obok horyzontu, co się za nim skrywa, co nie-zrozumiałe, bez-sensowne, rozplenione, nie-toż-same.

Koło Heideggera nie dopuszcza takiego wykoślawienia, gdyż także ono koniec końców - jest kołem części i całości. Wprawdzie autor Bycia i czasu wskazuje na niemożliwość ontologicznego ujęcia i określenia całościowego bycia jestestwa, jednak nazywa tę niemożliwość „pozorną”. Tym bowiem, co stanowi o całościowej egzystencji Dasein, jest śmierć: najbardziej ostateczna możliwość bycia, możliwość nie-bycia-już-tu-oto. Wbrew Heideggerowi, a za Derrida, Caputo twierdzi jednak, że śmierć jest nie tyle ostateczną możliwościa, ile - właśnie - niemożliwościa: czymś, co stanowi wyłom w intencjonalnych projektach Dasein i sprawia, że wypada ono z koła hermeneutycznego, albo raczej - co dokonuje zwi(ch)nięcia samego koła.

\section{Koło zwi(ch)nięte}

Jeśli więc koło hermeneutyczne nieuchronnie traci perspektywę całościowa, to nie tylko ustanawia sensy, ale i nieustannie je gubi. Faktyczne życie - jak mówi Caputo - jest „złamane” albo „załamane” (DH, 50), niemożliwe do uładzenia. Skoro Dasein to byt, któremu w jego byciu o nie samo chodzi, byt zatroskany, którego projekty podlegaja permanentnej rewizji, którego bycie nie może zostać wstrzymane, unieruchomione, ustatycznione (i ustatecznione) na wzór bytu-w-sobie, to jego projekty wystawione zostaja na ciagłą de(kon)strukcję, permanentne załamywanie się.

Na czym ta de(kon)strukcja polega? Projekcyjny charakter rozumienia skutkuje wychyleniem Dasein w przyszłość, owo wychylenie dokonuje się zaś ze względu na całą uprzedniość i teraźniejszość jego doświadczenia i rozumienia. Troska ma więc miejsce nie tyle w następstwie, ile w jedności trzech ekstaz czasowych: przeszłości, teraźniejszości i przyszłości. Oznacza to, że następuje w niej swoiste zwichnięcie czasu: teraźniejszość nigdy nie jest spójna i zwarta, „teraz” nigdy się nie aktualizuje, stanowiąc raczej przestrzeń „pomiędzy”: pomiędzy ,jeszcze nie” przyszłości i „już nie” przeszłości. Jak pokazuje w Widmach Marksa Derrida, potoczne rozumienie teraźniejszości jest tu mylące, ale też bardzo znaczące - tym bowiem, co

${ }^{31}$ M. Białoszewski, Choroba, [w:] tegoż, Wiersze, Warszawa 2003, s. 439.

\begin{tabular}{l|l} 
Patryk Szaj & 238 \\
&
\end{tabular}


myśli blisko siebie „teraźniejszośś” (łac. praesenti) i „obecność” (łac. praesentia), jest metafizyka ${ }^{32}$. Dokonywana przez nia „ontologizacja czasu” sprawia, że ujmujemy go jako byt pośród innych bytów, nie zaś - jako bycie: „żeby mówić [...] o obecności [du présent] [...] należy $z$ góry rozumieć, czym jest czas, czym jest owo ens w praes-ens" ${ }^{33}$. Jak komentuje tę kwestię, w bardzo caputiańskim stylu, Andrzej Marzec:

Charakterystycznymi cechami czasu i zanurzonej w nim dynamicznej rzeczywistości są upływ i przemijanie, czyli osobliwy stan pomiędzy byciem a niebyciem. Wspomnianego ruchu nie należy jednak wiązać z teleologicznym dążeniem czy też progresywnym posuwaniem się naprzód, lecz raczej ze zmiennością i nieuchwytnością. Ulotność zjawisk, ich niestałość i płynność wzbudzaja mniej lub bardziej uzasadnioną chęć ich zatrzymania oraz utrwalenia [...]. Proces ontologizacji to nic innego jak wytwarzanie iluzji obecności. Ma miejsce wtedy, gdy za pomoca metafizyki konserwujemy przemijającą rzeczywistość i nadajemy jej zbyt wiele istnienia ${ }^{34}$.

Ontologizacja wstrzymuje upływ, nadaje pozór stałości temu, co zmienne, procesualne, przemijające. Czym jednak jest owo zwichnięcie czasu, które skazuje wszelkie projekty ontologiczne na niepowodzenie, wszelkie koło hermeneutyczne na utratę perspektywy całościowej? Z pewnością nie jest ono skutkiem jakiegoś intencjonalnego działania podmiotu, przeciwnieto sam czas, by tak rzec, go doświadcza. Żeby to ukazać, Derrida dokonuje interpretacji słynnej frazy z Hamleta Williama Shakespeare'a: „The time is out of ioynt: Oh cursed spight / that ever I was borne to set it right". Brak tu miejsca na dokładniejsze omówienie zabiegu Derridy ${ }^{35}$, jego intencje dobrze oddaja jednak co najmniej dwa polskie tłumaczenia Hamleta przekładające „out of joint” właśnie jako „zwichnięcie”: Macieja Słomczyńskiego („Czasie zwichnięty! - Jak ci nie złorzeczyć? /Po cóż rodziłem się, by cię wyleczyć?"36) oraz Władysława Tarnawskiego (,Zwichnięty czas, w przeklętym ja momencie /Rodziłem się, by leczyć to zwichnięcie" ${ }^{37}$ ). Zwichnięcie czasu oznacza jego wypadnięcie z torów, z zawiasów, czy - właśnie - z orbity koła hermeneutycznego, rozstrojenie i wywrócenie do góry nogami, które „niesie ze sobą szok poznawczy" ${ }^{38}$, gdyż przerywa płynność ruchów. Koło hermeneutyczne

${ }^{32}$ Zob. na ten temat J. Derrida, Widma Marksa. Stan dtugu, praca żałoby i nowa międzynarodówka, przeł. T. Załuski, Warszawa 2016.

${ }^{33}$ Tenże, Przemoc i metafizyka. Esej o myśli Emmanuela Lévinasa, przeł. K. Matuszewski i P. Pieniążek, [w:] tegoż, Pismo filozofii, Kraków 1992, s. 194.

${ }^{34}$ A. Marzec, Widmontologia. Teoria filozoficzna i praktyka artystyczna ponowoczesności, Warszawa 2015, s. 192.

${ }^{35}$ Zob. J. Derrida, Nakazy Marksa, [w:] tegoż, Widma Marksa..., s. 19-89.

${ }^{36}$ W. Shakespeare, Hamlet, przeł. M. Słomczyński, Kraków 1995, s. 77.

${ }_{37}$ Tenże, Hamlet, królewicz duński, przeł. W. Tarnawski, Wrocław 1966, s. 61.

${ }^{38}$ A. Marzec, dz. cyt., s. 213. 
się zacina, cyrkularny nawrót zostaje złamany, zwichnięcie odbiera sprawność i sprawczość, wybija z rytmu, podważa intencjonalność.

Co więcej jednak, zwichnięcie nie jest stanem przejściowym: koło hermeneutyczne-jako koło temporalne - doświadcza go chronicznie i przewlekle. By to uargumentować, odwołać się można do myśli filozofa skądinąd nie tak bliskiego Derridzie i tradycji hermeneutycznej, mianowicie do Giorgia Agambena. W książce Homo sacer wprowadził on pojęcie stanu wyjątkowego, czyli stanu, który nie tylko wykracza poza „normalna” organizację czasu i przestrzeni życia wspólnoty, ale także zdaniem włoskiego filozofa stanowi podstawową strukturę prawną nowoczesnej biopolityki. Stan wyjątkowy wprowadzany jest bowiem po to, by uporządkować pierwotnie chaotyczna relację:

Ponieważ „nie istnieje żadna norma, która daje się zastosować do chaosu”, musi on zostać wpierw włączony do porządku poprzez stworzenie obszaru nierozróżnialności zewnętrza i wnętrza, chaosu i sytuacji normalnej: stanu wyjątkowego. Po to, by do czegokolwiek się odnosić, norma musi założyć to, co nie jest objęte żadną relacja, a jednocześnie ustanowić względem tego pewną relację $e^{39}$.

Stan wyjątkowy - paradoksalnie i wbrew swojej nazwie - wykazuje jednak według Agambena tendencję do wysuwania się na plan pierwszy i stawania się regułą organizacji państwa nowoczesnego. Żyjemy w permanentnym stanie wyjątkowym, wciąż doświadczając tego, co nie mieści się w ustalonym porządku prawnym i wciąż zawiązując nowe relacje pomiędzy owym porządkiem a nawiedzajacym go chaosem, poddawanym usystematycznieniu. Ruch porządkowania nigdy się nie kończy, tak jak ruch po kole hermeneutycznym. Na gruncie hermeneutyki takim „stanem wyjątkowym” byłoby więc nierozumienie wywoływane przez inność, które musi zostać przyswojone, wchłonięte, zorganizowane w obrębie określonego horyzontu. Jeśli jednak stan nierozumienia jest permanentny, to i koło chybia swojego celu, tak że właściwiej byłoby chyba określić je jako rozwijającą się w nieskończoność spiralę. Być może więc najlepszym jego określeniem dysponowałaby - znów - literatura, a dokładniej Fernando Pessoa:

[spirala - przyp. PS] to koło, które sunie w górę, nigdy się nie zamykając. [...] Ujmę to dokładniej: spirala to potencjalne koło, które się rozwija i nigdy się nie urzeczywistnia. Ale nie, ta definicja jest wciąż abstrakcyjna. Posłużę się konkretem i wszystko będzie jasne: spirala to wąż bez węża, owinięty pionowo wokół niczego ${ }^{40}$.

${ }^{39}$ G. Agamben, Homo sacer. Suwerenna wtadza i nagie życie, przeł. M. Salwa, Warszawa 2008, s. 32.

${ }^{40}$ F. Pessoa, Księga niepokoju Bernarda Soaresa, pomocnika księgowego w Lizbonie, przeł. M. Lipszyc, Izabelin 2007, s. 104.

\begin{tabular}{l|r} 
Patryk Szaj & $\mathbf{2 4 0}$ \\
&
\end{tabular}




\section{Etyczno-polityczne implikacje koła radykalnohermeneutycznego}

Radykalne koło hermeneutyczne wyraża więc z całą mocą dramatyzm ludzkiej egzystencji. Niemniej, ma ono także wyraźne pozytywne znaczenie etyczno-polityczne. Ponowoczesna myśl hermeneutyczna uczy, że tylko uczynienie (albo utrzymanie) wyłomu w logice koła hermeneutycznego otwiera przestrzeń wydarzenia - tego, co wyjątkowe, wykraczające poza intencjonalne projekty, niemieszczące się $\mathrm{w}$ horyzoncie sensu, absolutnie Inne. Wydarzenia, które jednocześnie byłoby darem - wydarzeniem. Takie zwichnięcie byłoby przestrzenią gościnności, przygotowywania w kole miejsca dla czegoś naprawdę obcego i wyjątkowego, albo też - jak w książce Prayers and Tears of Jacques Derrida pisze Caputo - kwestia nie właściwego wejścia w koło, ale „nauki [...], jak właściwe wyjść z koła” (PT, 160).

Etyczny wymiar ma oczywiście także koło nowoczesne, dążące do zniwelowania wyjściowych nieporozumień i przyswojenia obcości. Zadaniem tak zdefiniowanej hermeneutyki jest, jak pisał Gadamer, „rozjaśnianie rozumienia” będącego „udziałem we wspólnym sensie” ${ }^{41}$. Co jednak znaczy ów „wspólny” sens, jaka „,wspólnotę” on ustanawia albo raczej: jaka wspólnota stoi u jego podstaw? Jest to, rzecz jasna, wspólnota wspólnego horyzontu, wspólnota otwarta, ale zasadniczo już zdefiniowana i ustalona. Wspólnota, która zamyka oczy na pojedyncze przypadki, a tego, co poza nia, w ogóle nie dostrzega. Dlatego właśnie Derrida i Caputo naciskają na konieczność utrzymywania zwichnięcia koła hermeneutycznego, na które tak czy owak jest ono zawsze już wystawione. Inność mieści się bowiem nie tylko na zewnątrz, ale także wewnątrz tożsamości. Rzucenie jest wprawdzie rzuceniem w dziedzictwo, w dar tradycji, w to, co wspólne, w Geschick wspólnoty, tak że - jak mówi Caputo - otwierana przez horyzont sensu „możliwość jest zarówno dziedziczna, jak i wybrana, co tłumaczy, dlaczego Heidegger używa tu aktywnego sformułowania "przekaz tradycji» (ein Sichüberliefern)" (RH, 88). Tak pojęta „tradycja” okazuje się jednak według Caputo zbyt „niewinna”, co uwidacznia się szczególnie w refleksji Gadamera:

Opisuje on ciagłość tradycji, ale pozostawia niezadanym pytanie o to, czy tradycja od początku jest czymś jednolitym. Nigdy nie pyta, w jakim stopniu gra tradycji jest grą władzy, a jej jedność - czymś narzuconym przez istniejące uprawnienia. Jego „tradycja” jest nieczuła na nietzscheańską podejrzliwość, na foucaultowska genealogię. Nie mierzy się on z pęknięciami wewnątrz tradycji, z jej wrażliwością na różnice, z jej potencjałem opresyjnym. $(\mathrm{RH}, 112)$

${ }^{41}$ H.-G. Gadamer, Koto jako struktura rozumienia..., s. 228. 
Dla etyki radykalnohermeneutycznej ważniejsze zaś niż prawa i reguły rządzące życiem wspólnoty są pojedyncze przypadki, jednostkowe katastrofy, które wołaja o sprawiedliwość (HTRK, 55). Za Derrida zapytuje ona o wyrzutków, uchodźców, bezpaństwowców - tych wszystkich, którzy nie mieszczą się w jakiejkolwiek wspólnocie, w jakimkolwiek horyzoncie. Tę różnicę pomiędzy hermeneutyką nowoczesną a ponowoczesną dobrze oddaje „poróżnienie” między Heideggerem a Derridą dotyczące - właśnie - kwestii zwichnięcia. W Powiedzeniu Anaksymandra niemiecki filozof sformułował podobne co Hamlet stwierdzenie o zwichnięciu czasu: „w czymś pękły spoiny”" Heideggera oznacza to radykalną niesprawiedliwość: $a$-dikia, wybrakowanie, utratę harmonijnej całości, która rodzi wymóg ponownego wypełnienia, nastawienia pęknięcia, przywrócenia sprawiedliwości pojętej jako pełnia: dikia. Derrida jest jednak takiej interpretacji przeciwny, twierdząc, że to raczej-jak już powiedzieliśmy - utrzymywanie zwichnięcia rodzi prawdziwa, niedekonstruowalną sprawiedliwość wobec tego, co pojedyncze, inne, niezauważane przez całościowy horyzont. Sprawiedliwość dotyczy bowiem zawsze jednostkowego wydarzenia, niepodpadającego pod ogólne kategorie, szczególnie kategorie prawne. To właśnie pojedynczość innego wymaga sprawiedliwości (MRH, 179), możliwej tylko dzięki zwichnięciu, otwierającemu koło hermeneutyczne na radykalną inkluzję, radykalną wspólnotowość (MRH, 263). Sprawiedliwość, jeśli istnieje, jest niedekonstruowalna, jest - jak Kafkowski człowiek ze wsi - „przed prawem” i zawsze występuje w liczbie mnogiej: nie ma jednej sprawiedliwości, jest ich niepoliczalnie wiele - niepoliczalnie wiele zwichnięć: „nie znamy wszystkich imion własnych sprawiedliwości [...]. Sprawiedliwość nie jest jedną rzecza, jednym imieniem, ale niekontrolowaną wielością imion. Justitia disseminativa sui" (AE, 89). I właśnie dlatego, kiedy Derrida pragnie afirmatywnie zdefiniować dekonstrukcję, mówi: „dekonstrukcja jest sprawiedliwością" ${ }^{43}$. Sprawiedliwość to wszakże nie rodzaj arché, ale raczej przestrzeń an-archii, przepaści pomiędzy projektami etyczno-politycznymi a kruchością faktycznego życia (DH, 189). To właśnie w tej przepaści, w tym zwichnięciu, w tej wyrwie w obecności „mieści” się sprawiedliwość, która - jak mówi Caputo - ,jest śladem, tego, co nadchodzi poza możliwościa” (PT, XXIV), uruchamia tym samym czas inny niż linearny, inny niż zaprojektowany przez metafizyczną teleologię bądź eschatologię - czas mesjaniczny:

Czas zwichnięty jest czasem mesjanicznym, czasem, który nie zamyka się w sobie, który zostaje strukturalnie wy-stawiony [ex-posed] na ze-wnętrze [out-side] zapobiegające zamknięciu. [...] Ruch sprawiedliwości jest ruchem poza zawiasy

${ }^{42}$ M. Heidegger, Powiedzenie Anaksymandra, przeł. J. Sidorek, [w:] tegoż, Drogi lasu, Warszawa 1997, s. 286.

${ }^{43}$ J. Derrida, The Force of Law. The „Mystical Foundation of Authority”, przeł. M. Quaintance, "Cardozo Law Review" 1990, nr 5-6, s. 945. 
i zastałe spoiny prawa ku widmu innego, który wykoleja mnie z mojego zafiksowania na teraźniejszości, którego zjawienie się przede mną (prévenance) wytrąca mnie z równowagi, wciagając mnie w eksces rozproszenia [dis-juncture]. (PT, 123)

Czy jednak takie wykolejenie koła w ogóle jest możliwe? Jako się rzekło, z koła nie można po prostu wyjşć. W rzeczywistości nie można do niego nawet wejść - zawsze już w nim się jest. Chodziłoby więc ani nie o to, jak właściwe wkroczyć w koło (Heidegger), ani nie o to, jak właściwe je opuścić (Derrida), ale o to, jak je właściwe zwichnaćć, od której strony otworzyć je na zjawienie się daru, zjawienie się niemożliwego:

Marzenie i pragnienie daru [...] sa pasją i pragnieniem przekroczenia koła, nawet jeśli nie pozostaja całkowicie poza kotem. Właśnie to ma na myśli Derrida, gdy mówi o impulsie napędzającym koło, o niemożliwym impulsie, który zamieszkuje koło i wprawia je w ruch, pragnąc, by przestało ono być idealnym kołem, by lekko się wykrzywiło i by nie stało w martwym punkcie. (PT, 172)

„Koło nie może poruszać się bez daru, a dar nie miałby nic do przekroczenia bez koła" (PT, 173). Dlatego zwichnięcie jest także zwinięciem: Verwindung, permanentna transgresja koła hermeneutycznego dokonywana nie przeciw niemu, ale dla jego własnego dobra, wykraczaniem poza koło świadomym, że nigdy nie da się wykroczyć z niego całkowicie, sfałdowaniem, odbieraniem kołu pretensji do całości (whole), a więc pozbawianiem go „zdrowia” (wholesome), a nawet „świętości” (holy) w imię zanieczyszczenia, rozplenienia, kontaminacji, fragmentaryzacji niosacych dobrą nowinę sprawiedliwości. „Czy to w ogóle się zdarza? Nigdy nie wiadomo tego na pewno” ${ }^{44}$.

Jeśli więc nowoczesne koło hermeneutyczne poruszało się pomiędzy potencjalnością i aktualnością, ruch koła ponowoczesnego odbywa się raczej pomiędzy możliwością i... niemożliwościa. „Niemożliwe” byłoby tym, co nie mieści się w horyzoncie otwieranym przez koło, co wywołuje eksces i ,szokuje nasze oczekiwania, co zatem zależy od antycypujących oczekiwań i danych z góry horyzontów, które zostały określone zbyt wąsko lub ze zbyt małą tolerancją" (PT, 22). Niemożliwe nie jest przeciwieństwem możliwego. Podobnie jak hermeneutyka ponowoczesna w stosunku do hermeneutyki nowoczesnej, pozostają one do siebie w relacji Verwindung, nie Überwindung. Niemożliwe dokonuje zwichnięcia i zwinięcia możliwości, otwierając ją na to, co ponad nia, czyniąc w niej miejsce dla inności, miejsce dla sprawiedliwości. „Trzeba iść tam, dokąd iść nie można”, jak mówił Angelus Silesius, jak powtarzał za nim Derrida ${ }^{45}$, i jak wielokrotnie powtarza Caputo (PT,

${ }^{44}$ J. Derrida, Psyche. Odkrywanie innego, przeł. M.P. Markowski, [w:] Postmodernizm. Antologia przektadów, red. R. Nycz, Kraków 1997, s. 98.

${ }^{45}$ Zob. tenże, Sauf le nom (Post-Scriptum), [w:] tegoż, On the Name, przeł. J.P. Leavey Jr., Stanford 1995, s. 75. 
49). To w istocie jedyna droga, która można podążać, albo którą cokolwiek może nadejść. „Jeśli idziesz ku możliwemu, nie dzieje się nic wyjątkowego. Jedynym wydarzeniem, wy-darzeniem lub odkrywaniem, jest odkrywanie niemożliwego" (PT, 50).

Czy znajdujemy się jeszcze w obrębie koła hermeneutycznego? A może uprawiamy już, jak mówi Caputo, „hermeneutykę bez hermeneutyki” (MRH, 3)? Jeśli tak, to owo „bez” nie byłoby żadną utrata, lecz - przeciwnie - przestrzenia otwarcia (PT, 71), nie znaczyłoby także całkowitego pożegnania $\mathrm{z}$ hermeneutyka. Raczej wskazywałoby na paradoksalny charakter owego „bez” wyznaczającego przestrzeń ze/wnętrza (with/out). Nie można wyjśćc z koła, trzeba wyjść z koła.

Życie bez hermeneutyki jest możliwe.

Życie bez hermeneutyki jest niemożliwe.

\section{BIBLIOGRAFIA}

Agamben G., Homo sacer. Suwerenna władza i nagie życie, przeł. M. Salwa, Warszawa 2008.

Białoszewski M., Choroba, [w:] M. Białoszewski, Wiersze, Warszawa 2003.

Caputo J.D., Against Ethics. Contributions to a Poetics of Obligation with Constant Reference to Deconstruction, Bloomington 1993.

Caputo J.D., Demythologizing Heidegger, Bloomington and Indianapolis 1993.

Caputo J.D., How to Read Kierkegaard, New York 2007.

Caputo J.D., More Radical Hermeneutics: On Not Knowing Who We Are, Bloomington and Indianapolis 2000.

Caputo J.D., Prayers and Tears of Jacques Derrida. Religion without Religion, Bloomington and Indianapolis 1997.

Caputo J.D., Radical Hermeneutics. Repetition, Deconstruction and the Hermeneutic Project, Bloomington and Indianapolis 1987.

Deleuze G., Różnica i powtórzenie, przeł. B. Banasiak, K. Matuszewski, Warszawa 1997.

Derrida J., Przemoc i metafizyka. Esej o myśli Emmanuela Lévinasa, przeł. K. Matuszewski i P. Pieniążek, [w:] J. Derrida, Pismo filozofii, Kraków 1992.

Derrida J., Psyche. Odkrywanie innego, przeł. M.P. Markowski, [w:] Postmodernizm. Antologia przekładów, red. R. Nycz, Kraków 1997.

Derrida J., Sauf le nom (Post-Scriptum), [w:] J. Derrida, On the Name, przeł. J.P. Leavey Jr., Stanford 1995.

Derrida J., The Force of Law. The „Mystical Foundation of Authority”, przeł. M. Quaintance, "Cardozo Law Review" 1990, nr 5-6.

Derrida J., Widma Marksa. Stan dtugu, praca żałoby i nowa międzynarodówka, przeł. T. Załuski, Warszawa 2016.

Dilthey W., Powstanie hermeneutyki, [w:] W. Dilthey, Pisma estetyczne, przeł. K. Krzemieniowa, Warszawa 1982. 
Dziuban Z., Obcość, bezdomność, utrata. Wymiary atopii wspótczesnego doświadczenia kulturowego, Poznań 2009.

Gadamer H.-G., Aktualność piękna. Sztuka jako gra, symbol i święto, przeł. K. Krzemieniowa, Warszawa 1993.

Gadamer H.-G., Koło jako struktura rozumienia, przeł. G. Sowiński, [w:] Wokót rozumienia. Studia i szkice z hermeneutyki, red. G. Sowiński, Kraków 1993.

Gadamer H.-G., Prawda i metoda. Zarys hermeneutyki filozoficznej, przeł. B. Baran, Warszawa 2004.

Heidegger M., Co zwie się myśleniem?, przeł. J. Mizera, Warszawa-Wrocław 2000.

Heidegger M., Bycie i czas, przeł. B. Baran, Warszawa 2010.

Heidegger M., Powiedzenie Anaksymandra, przeł. J. Sidorek, [w:] M. Heidegger, Drogi lasu, Warszawa 1997.

Kasperski E., Hermeneutyka. Teoria interpretacji, [w:] Literatura, teoria, metodologia, red. D. Ulicka, wyd. 2, Warszawa 2001.

Kierkegaard S., Powtórzenie. Próba psychologii eksperymentalnej przez Constantina Constantiusa, [w:] S. Kierkegaard, Powtórzenie. Przedmowy, przeł. i oprac. B. Świderski, Warszawa 2000.

Leśniewski N., O hermeneutyce radykalnej, Poznań 1998.

Marzec A., Widmontologia. Teoria filozoficzna i praktyka artystyczna ponowoczesności, Warszawa 2015.

Pessoa F., Ksiega niepokoju Bernarda Soaresa, pomocnika ksiegowego w Lizbonie, przeł. M. Lipszyc, Izabelin 2007.

Przyłębski A., Hermeneutyczna antropologia Wilhelma Diltheya, [w:] A. Przyłębski, Krytyka hermeneutycznego rozumu. Preliminaria, Kraków 2016.

Ricoeur P., Język, tekst, interpretacja, przeł. P. Graff, K. Rosner, wstęp K. Rosner, Warszawa 1989.

Rosner K., Narracja, tożsamość i czas, Kraków 2003.

Schleiermacher F., Hermeneutics and Criticism. And Other Writings, przeł. A. Bowie, Cambridge 1998.

Shakespeare W., Hamlet, przeł. M. Słomczyński, Kraków 1995.

Shakespeare W., Hamlet, królewicz duński, przeł. W. Tarnawski, Wrocław 1966.

Spanos W.V., Heidegger, Kierkegaard, and the Hermeneutic Circle: Towards a Postmodern Theory of Interpretation as Dis-closure, [w:] Martin Heidegger and the Question of Literature, ed. W.V. Spanos, Bloomington and London 1979.

Staiger E., Die Kunst der Interpretation. Studien zur deutschen Literaturgeschichte, München 1963.

Szondi P., Wprowadzenie do hermeneutyki literackiej, [w:] Wspótczesna myśl literaturoznawcza w Republice Federalnej Niemiec. Antologia, wybór, oprac. i wstęp H. Orłowski, Warszawa 1986. 
